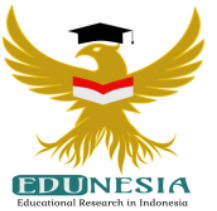

\title{
Kejenuhan Mahasiswa dalam Mengikuti Perkuliahan Daring dan Strategi Penanggulangannya
}

\author{
Dian Herdiana ${ }^{1}$; Rana Rudiana²; Supriatna ${ }^{3}$ \\ 1 Program Studi Administrasi Publik, UIN Sunan Gunung Djati Bandung, Indonesia \\ ${ }_{2}^{2}$ rogram Studi Administrasi Negara, Sekolah Tinggi Ilmu Administrasi (STIA) Cimahi, Indonesia \\ ${ }^{3}$ Supervisi Kelas, SMP Plus YPP Darussurur Cimahi, Indonesia \\ Corresponding Email: kyberdian@gmail.com, Phone Number:0852 xxxx xxxx
}

\section{Article History:}

Received: Dec 15, 2020

Revised: Dec 22, 2020

Accepted: Dec 24, 2020

Published: Jan 01, 2021

Keywords:

Online Lectures, Learning

Processes, Learning Strategies.

Kata Kunci:

Perkuliahan Daring, Proses

Pembelajaran, Strategi

Pembelajaran.

How to cite:

Herdiana, D., Rudiana, R., \& Supriatna, S. (2021). Kejenuhan Mahasiswa dalam Mengikuti Perkuliahan Daring dan Strategi Penanggulangannya. Edunesia: Jurnal Ilmiah Pendidikan, 2 (1): 293307.

This is an open access article under the CC-BY-NC-ND license

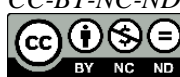

\begin{abstract}
This article is aimed at discussing college student's burnout in taking online lectures during the Covid-19 pandemic, the study focuses on two factors, namely: factors that cause college students being burnout and learning strategies that can be implemented to solve the college students burnout. The research method used a descriptive method with a qualitative approach, data sources consisted of primary data in the form of interviews with STIA Cimahi students and lecturers, and secondary data sources. The results of the study revealed that student burnout is caused by internal factors that come from himself, such as the unfamiliarity of online learning systems and external factors, such as the monotony of lecturers in delivering material. Therefore, in solving these problems, the researchers found several strategies that needed to be prepared by lecturers, namely changing online learning methods that would be more flexible, changing learning materials by accommodating contextual issues, and expanding learning media by utilizing social networks.
\end{abstract}

\begin{abstract}
Abstrak: Artikel ini ditujukan untuk mengkaji kejenuhan mahasiswa dalam mengikuti perkuliahan daring di masa pandemi Covid-19, kajian difokuskan kepada dua faktor, yaitu: faktor yang menyebabkan mahasiswa jenuh dan strategi pembelajaran guna menanggulangi kejenuhan mahasiswa. Metode penelitian menggunakan metode deskriptif dengan pendekatan kualitatif, sumber data terdiri dari hasil wawancara dengan mahasiswa dan dosen STIA Cimahi dan data sekunder. Hasil penelitian menunjukan kejenuhan mahasiswa disebabkan oleh faktor internal yang berasal dari dirinya sendiri seperti tidak terbiasanya belajar dengan sistem daring dan faktor eksternal, seperti monotonnya dosen dalam menyampaikan materi. Oleh karena itu, dalam mengatasi berbagai permasalahan yang ada, maka peneliti menemukan beberapa strategi yang perlu dipersiapkan oleh dosen, yakni mengubah metode pembelajaran daring yang lebih fleksibel, mengubah materi pembelajaran dengan mengakomodasi isuisu kontekstual, serta memperluas media pembelajaran dengan memanfaatkan jejaring sosial.
\end{abstract}




\section{A. Pendahuluan}

Pandemi Covid-19 yang ada di Indonesia telah mengubah metode pembelajaran secara nasional di seluruh jenjang pendidikan, termasuk perkuliahan di banyak institusi pendidikan tinggi yang selama ini banyak mempraktikkan perkuliahan tatap muka dan digantikan menjadi perkuliahan secara daring (Aji, 2020; Dewi, 2020). Perubahan tersebut secara empiris dilakukan relatif cepat tanpa adanya persiapan yang matang terlebih dahulu baik dari segi kurikulum pembelajaran maupun dari kesiapan sumber daya manusia dan infrastruktur teknologi informasi (Masriadi, 2020; Putra, 2020).

Kondisi tersebut dialami oleh perguruan tinggi Sekolah Tinggi Ilmu Administrasi (STIA) Cimahi yang selama ini mempraktikkan metode perkuliahan tatap muka menjadi perkuliahan secara daring, perubahan tersebut mulai dilakukan pada semester genap tahun ajaran 2019/2020, perubahan sistem perkuliahan tersebut didasarkan kepada alasan adanya kondisi penyebaran Covid-19 yang tidak memungkinkan perkuliahan secara tatap muka dilaksanakan.

Perubahan metode pembelajaran tersebut berakibat kepada banyak hal mulai dari sumberdaya manusia baik pendidik maupun tenaga kependidikan sampai dengan kepada infrastruktur teknologi penunjang perkuliahan daring. Dalam konteks STIA Cimahi, perubahan metode pembelajaran secara empiris tidak dipersiapkan dengan baik, kurikulum perkuliahan tatap muka masih dipergunakan dalam perkuliahan secara daring, sehingga secara substansi pokok pembelajaran dan capaian pembelajaran dalam perkuliahan daring sama dengan pembelajaran dalam perkuliahan tatap muka. Dalam perkembangannya, berbagai permasalahan muncul dalam perkuliahan daring yang diselenggarakan di STIA Cimahi mulai dari pemilihan platform pembelajaran daring, kapasitas dosen dalam pemanfaatan media perkuliahan daring, sampai dengan kepemilikan gawai elektronik dan jaringan internet. Baik dosen dan mahasiswa mengeluh mengenai tidak adanya sosialisasi dan pelatihan cara dan metode pembelajaran daring, minimnya bahan materi digital (seperti eBook) yang disediakan pihak kampus, tidak adanya subsidi kuota internet sampai dengan terbatasnya jumlah staf yang mengelola perkuliahan daring.

Salah satu implikasi dalam permasalahan tersebut yaitu memunculkan kejenuhan mahasiswa dalam mengikuti perkuliahan daring yang mana apabila dilihat dari pengertian kejenuhan belajar sebagaimana diutarakan oleh Hakim (2004) sebagai kondisi mental ketika seseorang mengalami rasa bosan dan lelah sehingga berdampak kepada timbulnya rasa lesu, tidak bersemangat, atau tidak bergairah untuk melakukan aktivitas belajar, maka kondisi tersebut dialami oleh mahasiswa di STIA Cimahi yang mana mahasiswa merasa bosan untuk mengikuti perkuliahan daring. Hal ini sejalan dengan aktivitas perkuliahan daring yang mana mahasiswa yang mengikuti perkuliahan daring jumlahnya berkurang setiap minggunya, keaktifan dalam berdiskusi menjadi berkurang dan sesi tanya jawab dalam perkuliahan secara daring menjadi minim dilakukan (Hasil Observasi, 2020). Kondisi tersebut sejalan pula dengan pemahaman Pines dan Aronson (dalam Mubiar, 2011) yang menjelaskan bahwa kejenuhan belajar merupakan suatu kondisi belajar yang bersifat emosionalitas yang disebabkan oleh kondisi lelah dan jenuh terhadap proses belajar yang semakin meningkat dan adanya tuntunan kebutuhan yang tinggi.

Kejenuhan mahasiswa dalam mengikuti perkuliahan daring apabila dilihat dari 3 (tiga) aspek kejenuhan belajar berdasar Maslach Burnout Inventory-Student Survey (Khairani, 2013; Muna, 2013) yang dilakukan melalui proses wawancara dengan Mahasiswa STIA 
Cimahi Angkatan 2018, maka didapat hasil sebagai berikut: Pertama, keletihan emosi (emotional exhaustion) yang mana adanya rasa tidak semangat dalam belajar dan merasa energinya terkuras. Hal ini dialami oleh mahasiswa STIA Cimahi dalam mengikuti perkuliahan daring, kebosanan terjadi ketika diharuskan dalam satu hari harus berjam-jam menatap gawai elektronik dan menyimak perkuliahan yang sedang berlangsung. Kedua, depersonalisasi (cynism) atau rasa tidak nyaman mengikuti pembelajaran dalam kelas. Hal ini dalam perkuliahan daring ditunjukan oleh mahasiswa STIA Cimahi dengan cara menonaktifkan kamera dan speaker agar mereka tidak terlihat oleh dosen dan rekan satu kelasnya untuk kemudian melakukan aktivitas lain seperti bermain game di gawai elektronik ketika perkuliahan daring tengah berlangsung. Ketiga, menurunnya keyakinan akademik (reduce academic efficacy) seperti tidak memiliki rasa percaya diri dan tertekan. Hal ini ditujukan oleh mahasiswa STIA Cimahi dengan terlambat mengumpulkan tugas atau jawaban baik dalam ujian tengah semester maupun dalam ujian akhir semester, serta mengerjakan tugas secara asal-asalan. Ketiga kondisi tersebut mengindikasikan bahwa mahasiswa STIA Cimahi mengalami kejenuhan dalam mengikuti perkuliahan daring, sehingga berimplikasi kepada capaian pembelajaran dalam perkuliahan daring yang tengah dilaksanakan (Hasil Observasi, 2020).

Uraian mengenai permasalahan tersebut di atas mendorong peneliti melakukan kajian mengenai kejenuhan mahasiswa dalam mengikuti perkuliahan daring yang diselenggarakan di STIA Cimahi, perlu adanya upaya untuk mengungkap faktor-faktor apa saja yang menjadi penyebab mahasiswa merasa jenuh dalam mengikuti perkuliahan daring, serta strategi apa yang harus dilakukan dalam meminimalisir kejenuhan mahasiswa dalam mengikuti perkuliahan daring tersebut. Tujuan dari adanya kajian ini yaitu agar diperoleh gambaran mengenai permasalahan dalam pembelajaran daring sehingga dapat dijadikan bahan pertimbangan untuk memperbaiki sistem perkuliahan daring agar lebih baik di semester yang akan datang.

\section{B. Metode}

Analisis terhadap permasalahan kejenuhan mahasiswa dalam mengikuti perkuliahan daring dikaji melalui metode penelitian deskriptif dengan pendekatan kualitatif. Sumber data dalam dalam artikel ini terdiri dari 2 (dua), yaitu: Pertama, data primer yang diperoleh dari informan yaitu mahasiswa Angkatan Tahun 2018 Kelas B dan kelas C yang tengah mengikuti perkuliahan semester ganjil tahun ajaran 2020/2021, serta dosen yang mengampu mata kuliah di kelas tersebut. Wawancara terhadap mahasiswa ditujukan untuk menggali informasi mengenai persepsi mahasiswa mengenai perkuliahan daring, sikap yang ditunjukan mahasiswa terhadap perkuliahan daring dan permasalahan yang mengganggu dalam perkuliahan daring yang menunjukan kecenderungan perilaku jenuh. Wawancara terhadap dosen ditujukan untuk menggali seperti apa persepsi dan sikap dalam perkuliahan daring, seperti apa proses perkuliahan daring yang diberikan, masalah apa yang dihadapi, perilaku mahasiswa seperti apa yang dapat diidentifikasi sebagai perilaku jenuh mahasiswa dalam mengikuti perkuliahan daring, serta strategi pembelajaran apa yang dilakukan untuk meminimalisir kejenuhan mahasiswa dalam mengikuti perkuliahan daring.

Observasi dilakukan terhadap mahasiswa STIA Cimahi Angkatan 2018 dalam semester ganjil tahun ajaran 2019/2020. Fokus observasi ditujukan untuk mengidentifikasi tantangan dan kendala dalam perkuliahan daring, serta perilaku mahasiswa yang 
ditunjukan dalam mengikuti perkuliahan daring yang menunjukan adanya kecenderungan jenuh. Teknik analisis data dalam artikel ini dilakukan melalui 3 (tiga) macam kegiatan yang saling berhubungan selama kegiatan penelitian yang didasarkan kepada pendapat dari Creswell (2007) yang terdiri dari: Pertama, tahap reduksi data. Kedua, tahap display atau penyajian data. Ketiga, penarikan kesimpulan. Data dan informasi yang didapat mengenai kejenuhan mahasiswa dalam mengikuti perkuliahan daring tersebut dilakukan pengujian keabsahan data melalui teknik triangulasi yang mana data yang diperoleh di check, re-check dan cross-check antara data yang satu dengan data yang lainnya sehingga pada akhirnya akan menghasilkan suatu gambaran yang real dan valid (Sugiyono, 2010).

\section{Hasil dan Pembahasan}

Perubahan metode perkuliahan dari tatap muka menjadi metode perkuliahan daring di masa pandemi Covid-19 menjadi tantangan tersendiri bagi penyelenggaraan perkuliahan daring, adanya kecenderungan mahasiswa yang merasa jenuh harus disikapi sebagai masukan dalam penyelenggaraan perkuliahan daring. Menemukenali faktor-faktor penyebab mahasiswa jenuh dalam mengikuti perkuliahan daring, serta strategi pembelajaran guna mengatasi pembelajaran daring perlu untuk dilakukan guna memperbaiki penyelenggaraan perkuliahan daring di masa yang akan datang.

\section{Permasalahan Pembelajaran Daring di Masa Pandemi Covid-19}

Pembelajaran daring di masa pandemi Covid-19 memunculkan berbagai permasalahan, baik permasalahan yang langsung berkaitan dengan penyelenggaraan pembelajaran daring maupun permasalahan di luar teknis pembelajaran daring yang secara langsung berpengaruh terhadap pembalajaran daring. Permasalahan yang sering muncul dalam pembelajaran daring yaitu masalah sumber daya manusia baik dari sisi pendidik, tenaga kependidikan maupun peserta didik, masalah yang menyangkut ketersediaan infrastruktur teknologi seperti gawai internet, platform media pembelajaran daring, sampai dengan ketersediaan jaringan internet (Fahlevi, 2020; Kementerian Riset Teknologi dan Pendidikan Tinggi, 2016; Putra, 2020). Permasalahan tersebut mengindikasikan bahwa perubahan model pembelajaran tatap muka ke dalam pembelajaran daring masih dihadapkan kepada permasalahan yang berimplikasi kepada terganggunya capaian pembelajaran daring, sehingga para pemangku kepentingan menjadi wajib untuk menanggulangi permasalahan tersebut.

Permasalahan pembelajaran daring sebagaimana yang telah dijelaskan tersebut sejalan dengan permasalahan perkuliahan daring dalam perkuliahan yang tengah dilaksanakan di STIA Cimahi di masa pandemi Covid-19 saat ini, yang mana berbagai permasalahan dalam perkuliahan daring di STIA Cimahi dapat dijelaskan dalam tabel 1 berikut ini:

Tabel 1. Permasalahan dalam Perkuliahan Daring

\begin{tabular}{cll}
\hline Tahap & \multicolumn{1}{c}{ Permasalahan Bagi Dosen } & \multicolumn{1}{c}{ Permasalahan Bagi Mahasiswa } \\
\hline Perencanaan & $\begin{array}{l}\text { Minimnya sosialisasi perkuliahan } \\
\text { daring, } \\
\text { Minimnya pelatihan perkuliahan } \\
\text { daring, }\end{array}$ & $\begin{array}{l}\text { Minimnya sosialisasi perkuliahan } \\
\text { daring, } \\
\text { Minimnya pelatihan perkuliahan } \\
\text { daring, }\end{array}$ \\
\hline
\end{tabular}




\begin{tabular}{|c|c|c|}
\hline Tahap & Permasalahan Bagi Dosen & Permasalahan Bagi Mahasiswa \\
\hline & $\begin{array}{l}\text { Rendahnya penyusunan materi } \\
\text { digital/virtual. }\end{array}$ & \\
\hline Pelaksanaan & $\begin{array}{l}\text { Adaptasi perkuliahan daring, } \\
\text { Penguasaan TIK, } \\
\text { Materi perkuliahan daring, } \\
\text { Media perkuliahan daring, } \\
\text { Jaringan internet. }\end{array}$ & $\begin{array}{l}\text { Adaptasi perkuliahan daring, } \\
\text { Penguasaan TIK, } \\
\text { Kepemilikan gawai elektronik/ } \\
\text { gadget, } \\
\text { Jaringan internet. }\end{array}$ \\
\hline
\end{tabular}

Sumber: Hasil Analisis Wawancara, 2020.

Berdasarkan kepada tabel 1 tersebut di atas, maka secara empiris perkuliahan daring di STIA Cimahi dibagi ke dalam dua tahap proses perkuliahan, yaitu permasalahan yang menyangut mengenai perencanaan perkuliahan daring dan permasalahan yang menyangkut pelaksanaan perkuliahan daring. Baik dosen maupun mahasiswa memiliki permasalahan dalam perkuliahan daring yang mana permasalahan tersebut terbuka kemungkinan untuk berdampak kepada tidak terselenggaranya perkuliahan daring secara optimal.

Permasalahan perkuliahan daring bagi dosen dalam proses perencanaan yaitu sosialisasi perkuliahan daring yang mana adanya peralihan dari perkuliahan secara tatap muka menjadi perkuliahan daring di masa pandemi Covid-19 tidak diikuti oleh sosialisasi dan pelatihan perkuliahan daring, sehingga dosen yang sebelumnya tidak pernah melaksanakan perkuliahan daring harus mencari berbagai referensi secara mandiri mengenai metode perkuliahan daring agar dapat melaksanakan perkuliahan daring.

Perkuliahan daring dalam proses perencanaannya harus pula melakukan penyusunan materi secara virtual atau digital, hal ini dilakukan atas dasar tidak lagi dimungkinkan untuk memberikan materi secara langsung berupa buku cetak atau bahan materi lainnya kepada mahasiswa, mengingat antara satu mahasiswa dengan mahasiswa yang lainnya memiliki perbedaan tempat tinggal. Dalam proses penyusunan materi untuk perkuliahan daring lebih kepada penyusunan materi dalam bentuk Power Point (PPT) atau dalam bentuk Portable Document Format (PDF), mengenai materi dan capaian pembelajaran masih didasarkan kepada kurikulum berbasis perkuliahan tatap muka yang telah ada, sehingga secara substansi antara perkuliahan tatap muka dan perkuliahan daring menggunakan kurikulum yang sama beserta dengan capaian pembelajaran yang sama pula. Hal ini menjadi kekurangan dalam proses perencanaan pembelajaran daring yang mana kurikulum beserta dengan capaian pembelajarannya seharusnya didasarkan kepada pendekatan perkuliahan daring. Hal ini di satu sisi dapat dimaklumi mengingat adanya wabah Covid-19 yang menyebar secara cepat, sehingga tidak memungkinkan disusun kurikulum dan pencapaian pembelajaran berbasis daring dalam waktu singkat.

Permasalahan pembelajaran daring dalam proses pelaksanaannya menuntut dosen untuk mengubah metode pembelajaran dari yang biasanya dilakukan secara tatap muka menjadi pembelajaran daring, hal ini tentu saja menuntut adaptasi baru bagi dosen yang harus segera terbiasa dengan metode perkuliahan daring yang mana mahasiswa berada dalam ruang yang berbeda dan dosen harus terbiasa dan mampu menguasai kelas perkuliahan daring sekalipun memiliki keterbatasan visual yang tidak bisa melihat keseluruhan kondisi dimana mahasiswa tersebut mengikuti perkuliahan daring, seperti 
tidak bisa melihat apakah kondisi di sekitar mahasiswa kondusif untuk perkuliahan daring atau sebaliknya.

Permasalahan lainnya yaitu materi pembelajaran daring yang mana dalam prakteknya dosen hanya memberikan materi pembelajaran dalam bentuk Power Point (PPT) dan Portable Document Format (PDF) kepada mahasiswa secara langsung dalam perkuliahan daring, pembuatan materi dalam bentuk video atau materi digital lainnya menjadi sulit untuk dilakukan, baik dikarenakan keterbatasan pengayaan materi dosen maupun dikarenakan keterbatasan penguasaan Teknologi Informasi dan Komunikasi (TIK). Media pembelajaran daring pun menjadi tantangan tersendiri bagi dosen yang harus menggunakan berbagai media pembelajaran daring, perubahan dari media pembelajaran menggunakan aplikasi Google Classroom di awal perkuliahan semester genap tahun ajaran 2019/2020, kemudian diganti dengan menggunakan aplikasi perkuliahan Siakad di semester ganjil tahun ajaran 2020/2021, dan kemudian harus pula diikuti oleh perkuliahan teleconference melalui aplikasi Zoom atau Google Meet. Berbagai media pembelajaran tersebut harus diadopsi dan dipahami dengan baik oleh dosen dalam waktu yang singkat. Permasalahan lainnya yaitu jaringan internet yang tidak stabil di beberapa wilayah, sehingga secara langsung menggangu jalannya perkuliahan secara daring.

Permasalahan perkuliahan daring bagi mahasiswa secara umum dibagi kedalam dua tahapan yaitu dalam tahap perencanaan dan dalam tahap pelaksanaan. Dalam tahap perencanaan sama halnya dengan dosen yang tidak menerima sosialisasi dan pelatihan dalam melaksanakan perkuliahan daring, maka mahasiswapun dalam perkuliahan daring tidak diberikan sosialisasi dan pelatihan, mahasiswa dituntut untuk dapat secara mandiri menguasai metode pembelajaran daring mulai dari penggunaan Google Classroom sampai dengan penggunaan aplikasi teleconference seperti Zoom dan Google Meet. Kondisi tersebut di satu sisi dapat dimaklumi mengingat bahwa adanya penyebaran pandemi Covid-19 yang begitu cepat maka tidak dimungkinkan mengumpulkan mahasiswa dalam satu tempat yang sama guna menyosialisasikan dan memberikan pelatihan perkuliahan daring yang akan dilaksanakan sebagai pengganti dari perkuliahan tatap muka, meskipun kondisi tersebut secara langsung berimplikasi kepada pemahaman mahasiswa dan dosen mengenai perkuliahan daring.

Permasalahan dalam pelaksanaan perkuliahan daring yang dihadapi mahasiswa untuk pertama kali yaitu masa adaptasi yang mana mahasiswa yang sebelumnya tidak pernah mengikuti perkuliahan daring, dituntut untuk terbiasa dan bisa dalam mengikuti perkuliahan daring. Dalam praktiknya adanya perbedaan penguasaan TIK diantara mahasiswa serta tidak semua mahasiswa memiliki laptop menyebabkan perkuliahan daring tidak dapat dilaksanakan secara optimal, bagi mahasiswa yang tidak memiliki laptop untuk dapat mengikuti perkuliahan daring, secara empiris menggunakan ponsel mereka meskipun dalam tampilan layar yang lebih kecil. Permasalahan lainnya yaitu tidak adanya jaringan internet yang stabil dan merata di tempat tinggal mahasiswa, sehingga dalam proses perkuliahan seperti menggunakan aplikasi teleconference, maka tidak stabilnya jaringan internet menyebabkan video yang diterima selama proses perkuliahan menjadi terputus-putus, sehingga berakibat kepada permasalahan dalam penyampaian materi pembelajaran.

Permasalahan perkuliahan daring sebagaimana hasil penelitian yang dijelaskan di atas, secara umum dialami juga di berbagai daerah dan institusi pendidikan yang mana permasalahan seperti tidak adanya kesiapan dalam pembelajaran daring, tidak adanya gawai internet dan jaringan internet yang tidak stabil berakibat kepada terhambatnya 
proses pembelajaran daring (Fahlevi, 2020; Jamaluddin dkk, 2020), sehingga di satu sisi permasalahan ini tidak hanya berakibat kepada tidak optimalnya pembelajaran daring, tetapi juga menyebabkan kejenuhan mahasiswa dalam mengikuti pembelajaran daring.

\section{Faktor-Faktor Penyebab Kejenuhan Mahasiswa dalam Mengikuti Perkuliahan Daring}

Belajar merupakan aktivitas mental (psikis) yang berlangsung dalam interaksi dengan lingkungannya yang menghasilkan perubahan yang relatif konstan, didasarkan kepada pemahaman tersebut, maka proses pembelajaran dapat menyebabkan kejenuhan yang mana kejenuhan dalam belajar disebabkan oleh aktivitas dari belajar yang dilakukan secara berulang-ulang (Syah, 2011). Berbagai perilaku dapat diidentifikasikan sebagai kondisi kejenuhan dalam belajar yang mana secara umum kejenuhan dalam belajar ditunjukan dengan adanya kesulitan dalam memproses dan memahami materi pembelajaran yang telah diberikan (Hakim, 2004; Khairani, 2013), kondisi tersebut merupakan fase yang mana proses pembelajaran harus dilakukan pembenahan guna meminimalisir kondisi psikis peserta didik agar tidak semakin merasa jenuh yang akan berimplikasi kepada terganggunya capaian pembelajaran. Berdasarkan kepada hasil penelitian terhadap mahasiswa di STIA Cimahi dalam mengikuti perkuliahan daring di masa pandemi Covid-19, maka bentuk-bentuk kejenuhan mahasiswa dalam mengikuti perkuliahan daring ditujukan dalam berbagai bentuk dapat dilihat dalam tabel berikut ini:

Tabel 2. Bentuk-bentuk Kejenuhan Mahasiswa dalam Mengikuti Perkuliahan Daring

\begin{tabular}{ll}
\hline \multicolumn{1}{c}{$\begin{array}{c}\text { Bentuk-bentuk } \\
\text { Kejenuhan }\end{array}$} & \multicolumn{1}{c}{ Uraian } \\
\hline Kehadiran berkurang & $\begin{array}{l}\text { Kehadiran dalam perkuliahan daring menjadi menurun } \\
\text { dengan menyertakan berbagai alasan atau argumentasi }\end{array}$ \\
\hline $\begin{array}{l}\text { Respons terhadap materi } \\
\text { yang diberikan minim }\end{array}$ & $\begin{array}{l}\text { Respons terhadap materi perkuliahan yang diberikan sebatas } \\
\text { kepada ucapan "iya, dapat dipahami", "terima kasih atas } \\
\text { materinya", "akan dipelajari dan dipahami lagi" dan } \\
\text { ungkapan serupa lainnya }\end{array}$ \\
\hline $\begin{array}{l}\text { Pertanyaan secara } \\
\text { langsung dijawab secara } \\
\text { singkat }\end{array}$ & $\begin{array}{l}\text { Apabila dosen menanyakan langsung dalam perkuliahan } \\
\text { secara teleconference, maka dijawab dengan singkat, analisis } \\
\text { tidak tajam dan terkadang tidak sesuai dengan konteks } \\
\text { materi yang tengah disampaikan }\end{array}$ \\
\hline $\begin{array}{l}\text { Minimnya interaksi dan } \\
\text { diskusi kelas }\end{array}$ & $\begin{array}{l}\text { Keaktifan dan diskusi dalam perkuliahan yang dilakukan } \\
\text { secara tatap muka yang biasanya aktif, menjadi minim } \\
\text { dilakukan atau jalannya diskusi menjadi kurang interaktif } \\
\text { dan hanya diikuti oleh sedikit mahasiswa, penyampaian } \\
\text { materi lebih kepada satu arah dari dosen kepada mahasiswa } \\
\text { dengan minimnya respons yang diberikan oleh mahasiswa }\end{array}$ \\
\hline $\begin{array}{l}\text { Pengerjaan tugas yang } \\
\text { cenderung asal-asalan }\end{array}$ & $\begin{array}{l}\text { Pengerjaan tugas yang cenderung menyalin dari materi yang } \\
\text { sudah diberikan, tanpa melengkapi dengan sumber referensi } \\
\text { lainnya yang relevan seperti dari buku dan artikel jurnal guna } \\
\text { memperkuat analisis terhadap pertanyaan yang diberikan }\end{array}$ \\
\hline
\end{tabular}




\begin{tabular}{lrl}
\hline \multicolumn{1}{c}{$\begin{array}{c}\text { Bentuk-bentuk } \\
\text { Kejenuhan }\end{array}$} & \multicolumn{1}{c}{ Uraian } \\
\hline $\begin{array}{l}\text { Mengumpulkan tugas } \\
\text { melebihi batas waktu } \\
\text { yang telah ditentukan }\end{array}$ & $\begin{array}{l}\text { Tugas yang seharusnya dikumpulkan tepat waktu, dengan } \\
\text { berbagai alasan maka dikumpulkan telat dan secara substansi } \\
\text { dari jawaban yang diberikan tidak komprehensif } \\
\text { sebagaimana maksud dalam pertanyaan dalam tugas }\end{array}$ \\
\hline $\begin{array}{l}\text { Jawaban ujian tidak } \\
\text { komprehensif } \\
\text { cenderung asal }\end{array}$ & dan $\begin{array}{l}\text { Jaban ujian sebatas kepada menjawab sesuai dengan } \\
\text { materi yang diberikan, kajian analisis tidak didasarkan } \\
\text { kepada sumber referensi lainnya dan tergantung kepada } \\
\text { materi perkuliahan yang telah diberikan, sehingga } \\
\text { mengakibatkan bobot penilaian yang diberikan dosen } \\
\text { menjadi berkurang }\end{array}$ \\
\hline
\end{tabular}

Sumber: Analisis Hasil Wawancara, 2020.

Berdasarkan kepada tabel 2 tersebut di atas, maka mahasiswa yang ada di STIA Cimahi menunjukan kejenuhan dalam mengikuti perkuliahan daring di masa pandemi Covid-19 ini dengan berbagai bentuk, hal ini baik yang disadari maupun yang tidak disadari oleh mahasiswa yang bersangkutan. Sejalan dengan bentuk-bentuk kejenuhan mahasiswa dalam mengikuti perkuliahan daring tersebut, maka faktor-faktor penyebab mahasiswa merasa jenuh dalam mengikuti perkuliahan daringpun beragam, hal ini dapat sebagaimana dapat dilihat dalam tabel berikut ini:

Tabel 3. Faktor-faktor Penyebab Kejenuhan dalam Mengikuti Perkuliahan Daring

\begin{tabular}{|c|c|c|}
\hline Sumber & Faktor & Penjelasan \\
\hline \multirow[t]{2}{*}{ Internal } & $\begin{array}{l}\text { Kebiasaan } \\
\text { Pembelajaran }\end{array}$ & $\begin{array}{l}\text { - Sudah terbiasa dengan perkuliahan tatap muka yang } \\
\text { mana proses perkuliahan menghadirkan interaksi } \\
\text { secara langsung antara dosen dan mahasiswa } \\
\text { - Proses adaptasi dan pembiasaan perkuliahan daring } \\
\text { yang memerlukan waktu } \\
\text { - Sulit menjaga semangat dan disiplin dalam mengikuti } \\
\text { perkuliahan daring }\end{array}$ \\
\hline & $\begin{array}{l}\text { Kepemilikan } \\
\text { Gawai Elektronik } \\
\text { dan Jaringan } \\
\text { Internet }\end{array}$ & $\begin{array}{l}\text { - Mengikuti perkuliahan daring menggunakan ponsel } \\
\text { dengan layar yang kecil (bagi yang tidak memiliki } \\
\text { laptop) dirasakan membosankan dalam waktu yang } \\
\text { cukup lama dan dengan intensitas yang sering } \\
\text { - Jaringan internet yang tidak stabil, sehingga } \\
\text { menyulitkan proses pembelajaran dan menyebabkan } \\
\text { kebosanan untuk mencari lokasi/tempat dengan } \\
\text { jaringan internet yang stabil }\end{array}$ \\
\hline Eksternal & $\begin{array}{l}\text { Proses } \\
\text { Pembelajaran }\end{array}$ & $\begin{array}{l}\text { - Materi yang diberikan sulit dipahami } \\
\text { - Sulitnya mencari referensi materi pendukung } \\
\text { - Cara penyampaian materi oleh dosen dirasakan } \\
\text { monoton } \\
\text { - Banyaknya tugas yang harus dikerjakan }\end{array}$ \\
\hline
\end{tabular}




\begin{tabular}{lll}
\hline Sumber & \multicolumn{1}{c}{ Faktor } & \multicolumn{1}{c}{ Penjelasan } \\
\hline \multirow{2}{*}{ Lingkungan } & - Anggota keluarga lainnya kurang memberi dukungan \\
& dalam pelaksanaan pembelajaran daring \\
& - Kondisi rumah atau lingkungan yang bising/berisik \\
\cline { 2 - 3 } Lingkungan & - Tidak ada/minimnya interaksi sosial dengan teman \\
Kampus & satu kampus secara langsung (tatap muka) \\
& - Tidak ada/minimnya diskusi mengenai materi \\
& perkuliahan secara langsung (tatap muka) yang biasa \\
& dilakukan ketika perkuliahan tatap muka \\
& - Pengerjaan tugas kelompok yang biasanya dilakukan \\
& di area kampus dan berkomunikasi secara langsung \\
& (tatap muka) menjadi tidak ada, sehingga tugas \\
& kelompok tersebut menjadi sulit untuk dikerjakan \\
\hline
\end{tabular}

Sumber: Analisis Hasil Wawancara, 2020.

Berdasarkan kepada tabel 3 tersebut di atas, maka faktor-faktor yang menjadi penyebab mahasiswa jenuh dalam mengikuti perkuliahan daring setidaknya disebabkan oleh faktor internal yang berasal dari diri sendiri mahasiswa yang bersangkutan dan faktor eksternal yang berasal baik dari proses pembelajaran maupun dari faktor lingkungan mahasiswa yang bersangkutan. Kedua faktor tersebut dapat dijelaskan sebagai berikut:

Pertama, faktor internal yang berasal dari diri sendiri yang mana mahasiswa merasa bahwa dalam perkuliahan daring dibutuhkan kemandirian dan disiplin dalam membagi waktu, hal ini berbeda dengan perkuliahan tatap muka yang mana mahasiswa sudah memiliki rutinitas pergi ke kampus untuk mengikuti perkuliahan, sedangkan dalam pembelajaran daring mahasiswa harus tetap tinggal di rumah, sedangkan bagi mahasiswa yang sudah bekerja maka seringkali urusan pekerjaan menyebabkan waktu untuk mengikuti perkuliahan menjadi berkurang, dikarena antara urusan pekerjaan dengan waktu perkuliahan seringkali bersamaan.

Faktor lainnya yaitu adanya kendala dalam kepemilikan gawai elektronik, khususnya laptop, sehingga mahasiswa yang tidak memiliki laptop harus mengikuti perkuliahan khususnya perkuliahan teleconference melalui ponsel yang mana sebagian mahasiswa mengakui bahwa mengikuti perkuliahan dengan menatap layar ponsel dalam waktu yang lama dan berulang-ulang menimbulkan kejenuhan, hal ini ditambah dengan jaringan internet yang kurang stabil sehingga harus mencari daerah yang memiliki jaringan internet yang stabil. Kondisi tersebut tidak jarang pada akhirnya mengakibatkan terganggunya proses perkuliahan yang tengah diikuti oleh mahasiswa.

Kedua, faktor eksternal merupakan faktor yang berasal dari luar diri mahasiswa yang bersangkutan baik dari keluarga maupun dari lingkungan sosial. Mahasiswa dalam proses perkuliahan secara tatap muka terbiasa melakukan diskusi dengan yang lainnya di lingkungan kampus mengenai materi dan tugas kelompok, sedangkan dalam perkuliahan daring di masa pandemi Covid-19 kondisi tersebut menjadi sulit untuk dilakukan, hal ini diperburuk apabila di dalam rumahnya terdapat interaksi yang intens antar sesama anggota keluarga sehingga mengikuti perkuliahan daring menjadi tidak fokus, terlebih lagi apabila rumahnya berada di lingkungan yang kurang kondusif seperti di pinggir jalan yang mana suara bising dari kendaraan bermotor dapat mengganggu perkuliahan khususnya pada saat 
perkuliahan teleconference. Berbagai permasalahan yang berasal dari eksternal tersebut pada akhirnya menimbulkan kejenuhan mahasiswa dalam mengikuti perkuliahan daring.

Kedua permasalahan tersebut menjadi faktor-faktor yang mengakibatkan mahasiswa jenuh dalam mengikuti perkuliahan daring, mahasiswa pada dasarnya memerlukan waktu untuk beradaptasi dengan perkuliahan daring baik dari segi metode pembelajaran maupun dari segi kesiapan, kedisiplinan dan kemandirian mahasiswa dalam membagi waktu antara perkuliahan dengan kehidupan sehari-hari.

\section{Strategi Pembelajaran dalam Mengurangi Kejenuhan Mahasiswa Mengikuti Pembelajaran Daring}

Istilah strategi pada awalnya banyak digunakan di lingkungan militer pada jaman dahulu untuk mengungkapkan penggunaan atau penyusunan rencana, garis besar haluan guna mencapai tujuan. Seiring dengan perkembangan jaman, istilah strategi digunakan dalam banyak bidang ilmu yang salah satunya digunakan dalam kajian pembelajaran yang kemudian dikenal dengan istilah strategi pembelajaran (Djamaroh, 2002; Fathurrohman \& Sutikno, 2007).

Strategi pembelajaran diartikan secara beragam oleh para ahli, seperti yang diungkapkan oleh Darmansyah (2010) yang menyatakan bahwa strategi pembelajaran yaitu proses pengorganisasian isi pelajaran, penyampaian pelajaran dan pengelolaan kegiatan pembelajaran dengan adanya penggunaan berbagai sumber belajar yang digunakan oleh guru dengan tujuan menunjang terciptanya proses pembelajaran yang efektif dan efisien, sejalan dengan pemahaman tersebut Freiberg \& Driscoll (1992) mengemukakan bahwa strategi pembelajaran digunakan untuk mencapai tujuan memberikan materi pelajaran dalam berbagai tingkatan pendidikan. Strategi pembelajaran dalam pedoman pemerintahan diartikan sebagai suatu perencanaan yang didalamnya berisi tentang rangkaian kegiatan yang dirancang guna mencapai tujuan pendidikan tertentu (Direktorat Tenaga Kependidikan, 2008). Dari pemahaman beberapa ahli tersebut, maka strategi pembelajaran secara umum diartikan dengan suatu rancangan kegiatan pembelajaran yang didalamnya memuat mengenai substansi, prosedur, metode dan sumber daya guna mewujudkan tujuan pembelajaran yang telah ditentukan.

Strategi pembelajaran dalam perkuliahan daring memiliki perbedaan dengan strategi pembelajaran dalam perkuliahan tatap muka, salah satu perbedaannya yaitu adanya pemanfaatan gawai elektronik dan akses internet yang menjadi media perkuliahan dan menghubungkan antara pendidik dengan peserta didik. Strategi pembelajaran daring dalam merespons kejenuhan mahasiswa dalam mengikuti perkuliahan daring pada dasarnya merupakan upaya yang dilakukan oleh pendidik yang dalam hal ini dosen agar mampu meminimalisir kejenuhan mahasiswa yang didasarkan kepada permasalahan yang diketemukan atau yang muncul, dalam hal ini permasalahan pembelajaran daring yang ada di STIA Cimahi sebagaimana telah dijelaskan sebelumnya. Strategi pembelajaran daring dalam merespons kejenuhan mahasiswa dalam mengikuti perkuliahan daring selama pandemi Covid-19 di STIA Cimahi setidaknya terdiri dari 3 (tiga) cara yang dapat dijelaskan melalui gambar 1 berikut ini: 


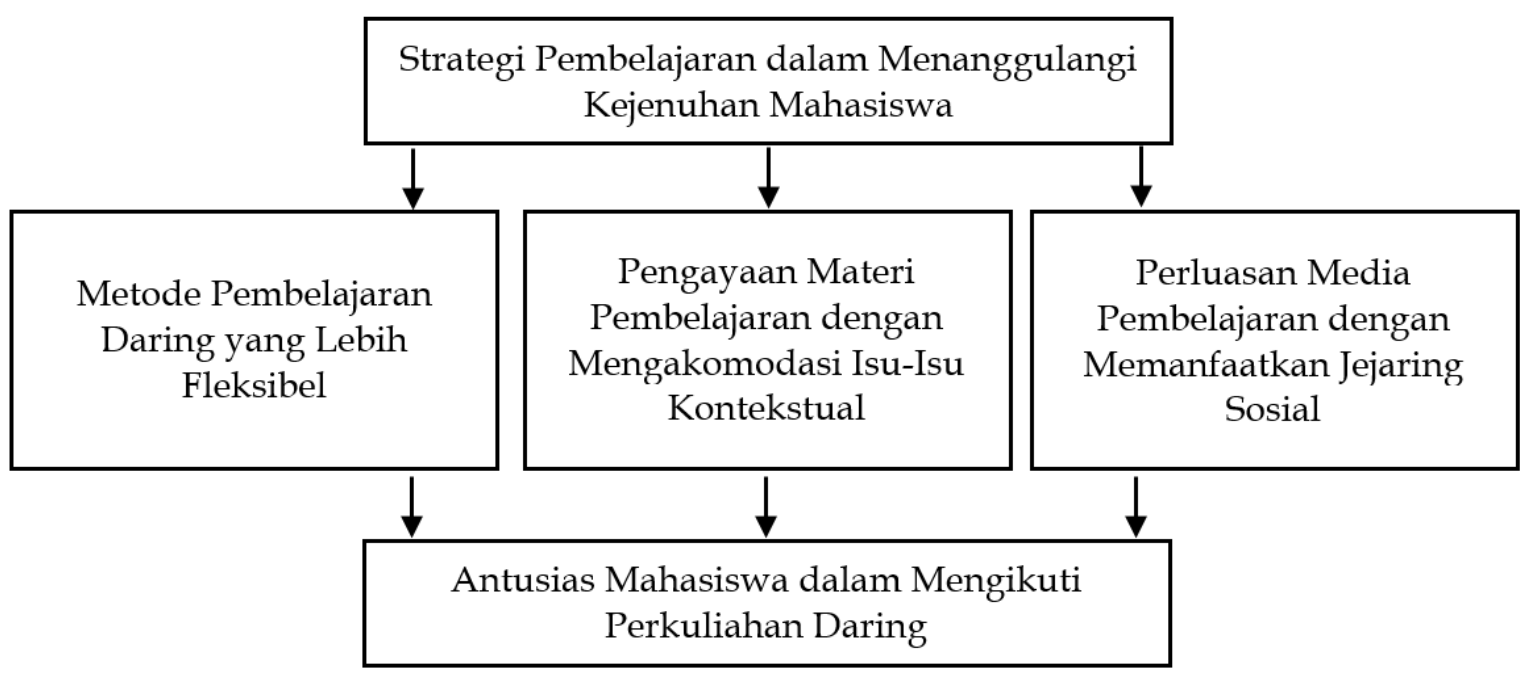

Gambar 1. Strategi Pembelajaran dalam Perkuliahan Daring

Berdasarkan kepada gambar 1 tersebut, maka strategi pembelajaran dalam menanggulangi kejenuhan mahasiswa dalam mengikuti perkuliahan daring setidaknya terdiri dari tiga aspek, yaitu mengubah metode pembelajaran daring yang lebih fleksibel, mengubah materi pembelajaran dengan mengakomodasi isu-isu kontekstual, serta memperluas media pembelajaran dengan memanfaatkan jejaring sosial. Ketiga aspek tersebut dapat dijelaskan sebagai berikut:

Pertama, fleksibilitas dalam pembelajaran daring menjadi bagian strategi pembelajaran guna mengurangi kejenuhan mahasiswa, hal ini sejalan dengan hasil penelitian yang telah dilakukan oleh Usman (2018) dan Fandianta dkk (2013) yang mengkaji tentang fleksibilitas pembelajaran dengan menggunakan metode blended learning yang mana kedua penelitian tersebut menghasilkan simpulan bahwa fleksibilitas belajar menjadi salah satu strategi pembelajaran yang mampu meningkatkan siswa didik dalam mengikuti pembelajaran. Fleksibilitas dalam konteks perkuliahan di STIA Cimahi mencakup fleksibilitas platform media pembelajaran dan fleksibilitas waktu pembelajaran, sehingga mahasiswa akan mengikuti pembelajaran daring dengan keberagaman metode pembelajaran.

Fleksibilitas platform perkuliahan dalam konteks pembelajaran daring di STIA Cimahi yaitu adanya kebebasan bagi dosen untuk menentukan platform media pembelajaran bagi terselenggaranya proses perkuliahan daring. Secara kelembagaan platform yang digunakan dalam pembelajaran yaitu melalui platform Siakad, sedangkan platform lainnya yaitu Google Meet, Zoom dan Google Calssroom. Dalam prakteknya, setiap minggu perkuliahan tidak hanya melalui platform Siakad, tetapi diselingi dengan perkuliahan teleconference melali aplikasi Google Meet dan Zoom. Hal ini ditujukan agar mahasiswa tidak merasa monoton harus mengikuti perkuliahan setiap minggu dengan aplikasi yang sama.

Fleksibilitas waktu diartikan sebagai pelaksanaan perkuliahan yang didasarkan kepada kesepakatan bersama anara mahasiswa dan dosen mengenai waktu perkuliahan, khususnya pada saat perkuliahan secara teleconference, semisal bagi mahasiswa kelas sore yang mana perkuliahan dijadwalkan sebagaimana disusun oleh lembaga dilaksanakan mulai dari pukul 19.00 WIB sampai dengan 21.00 WIB, dapat diselenggarakan lebih awal 
apabila pada jam sebelumnya tidak diselenggarakan perkuliahan secara teleconference, atau bahkan bisa dipindah di hari lainnya sesuai dengan kesepakatan antara mahasiswa dengan dosen.

Kedua, pengayaan materi pembelajaran dengan mengakomodasi isu-isu kontekstual yang mana berdasarkan hasil penelitian dari Kadir (2013) dan Afriani (2018) menyatakan bahwa kontekstualisasi pembelajaran dapat meningkatkan peserta didik dalam mengikuti pembelajaran. Pengayaan materi pembelajaran secara kontekstual di STIA Cimahi setidaknya didasarkan kepada dua pertimbangan, yaitu kesinambungan mata kuliah bidang-bidang administrasi negara dengan isu kontekstual dan pembaharuan pengetahuan mahasiswa mengenai isu-isu kontekstual. Mahasiswa STIA Cimahi mayoritasnya berasal dari program studi administrasi negara, hanya ada 10 orang yang berasal dari program administrasi bisnis, sehingga akomodasi isu-isu kontekstual sangat relevan dalam proses perkuliahan secara daring.

Akomodasi isu-isu kontekstual dalam prakteknya semisal dalam mata kuliah kebijakan publik, maka materi berbasis konseptual disinergiskan dengan isu kontekstual, semisal mahasiswa diberikan pemahaman mengenai konsep implementasi kebijakan publik, kemudian diberikan isu-isu mengenai kebijakan publik saat ini seperti isu penanggulangan Covid-19, kemudian mahasiswa dituntut untuk mencari referensi mengenai konsep dan teori implementasi kebijakan publik dan referensi mengenai penanggulangan Covid-19 dari berbagai sumber berita yang akhirnya dilakukan analisis konseptual dan teoritis. Bagi mahasiswa yang sudah bekerja semisal bekerja di instansi pemerintah, isu-isu yang diangkat bisa dikaitkan dengan dunia pekerjaannya, sehingga akan berkorelasi antara perkuliahan dengan pekerjaan.

Akomodasi isu-isu kontekstual tidak hanya dilakukan pada saat penyampaian materi semata, tetapi dalam keseluruhan pembelajaran daring mulai dari diskusi kelompok sampai dengan soal ujian semester. Hal ini dilakukan agar mahasiswa tidak merasa jenuh diberikan materi-materi konseptual dari buku atau jurnal, sehingga proses perkuliahan akan dinamis sesuai dengan situasi lingkungan sosial saat ini.

Ketiga, perluasan media pembelajaran. Stategi pembelajaran dengan menggunakan platform media sosial sebagaimana hasil penelitian dari Mustakim (2020) yang mengkaji mengenai pemanfaatan media sosial dalam pembelajaran daring di masa pandemi Covid19 dianggap efektif dalam proses pembelajaran daring. Dalam konteks perkulihan di STIA Cimahi, perluasan media pembelajaran dengan memanfaatkan jejaring sosial dinilai menjadi cara untuk mengurangi kejenuhan mahasiswa dalam perkuliahan daring, dosen bersifat fleksibel terhadap berbagai jejaring sosial yang dapat meningkatkan antusiasme mahasiswa dalam mengikuti perkuliahan daring, seperti jejaring sosial facebook dan twitter, bahkan jejaring sosial tidak hanya dijadikan sebagai media dalam proses pembelajaran, tetapi juga dapat dijadikan materi pembelajaran, semisal trending topic apa yang ada di twitter dalam satu minggu, kemudian disampaikan oleh dosen sebagai bahan materi perkuliahan. Dalam prakteknya dosen menyampaikan bahwa dalam satu minggu terakhir trending topic menyangkut isu vaksinasi Covid-19 yang mana cuitan lini masa ada yang mendukung dan ada yang menolak, kemudian topik tersebut dikaitkan dengan konteks konseptual semisal dikaitkan dengan konsep/teori persepsi dan opini publik, hal ini diharapkan selain akan menimbulkan sikap antusiasme juga akan mendorong mahasiswa untuk mencari informasi lanjutan mengenai topik materi yang disampaikan tersebut, sehingga perkuliahan daring tidak akan bersifat monoton. 
Penggunaan jejaring sosial dalam proses komunikasi antara mahasiswa dan dosen dapat pula dilakukan melalui Whatsapp dan Telegram, baik secara pribadi maupun melalui grup kelas, sehingga adanya kebeagaman media komunikasi selain diharapkan akan memudahkan proses komunikasi, juga akan meminimalisir kesulitan mahasiswa dalam mengikuti perkuliahan daring yang pada akhirnya diharapkan dapat mengurangi kejenuhan mahasiswa dalam mengikuti perkuliahan daring.

Ketiga strategi pembelajaran yang dilakukan dalam mengurangi kejenuhan mahasiswa dalam perkuliahan daring diharapkan mampu memberikan pemahaman dan kesan kepada mahasiswa bahwa perkuliahan daring merupakan salah satu metode pembelajaran selain pembelajaran tatap muka yang memiliki karakteristik dan daya tarik tersendiri, sehingga antusiasme dalam perkuliahan secara tatap muka harus pula dimiliki mahasiswa ketika mengikuti perkuliahan secara daring.

\section{Kesimpulan}

Pandemi Covid-19 telah mengubah sistem perkuliahan dari yang biasanya dilakukan secara tatap muka menjadi perkuliahan secara daring, berbagai permasalahan muncul dari perkuliahan daring mulai dari kesiapan mahasiswa dan dosen, materi pembelajaran daring, sampai dengan infrastruktur teknologi dan jaringan internet, permasalahan tersebut secara empiris telah berdampak bagi proses terselenggaranya perkuliahan daring yang diselenggarakan di STIA Cimahi.

Salah satu dampak dari perkuliahan daring yaitu memunculkan kejenuhan mahasiswa dalam mengikuti perkuliahan daring, hal ini antara lain disebabkan oleh faktor internal yang berasal dari dirinya sendiri seperti tidak terbiasanya belajar dengan sistem daring dan faktor eksternal, seperti monotonnya dosen dalam menyampaikan materi dan tidak adanya teman yang secara langsung dapat diajak untuk berdiskusi mengenai materi perkuliahan.

Strategi pembelajaran untuk menanggulangi kejenuhan mahasiswa dalam perkuliahan daring antara lain, yaitu mengubah metode pembelajaran daring yang lebih fleksibel, mengubah materi pembelajaran dengan mengakomodasi isu-isu kontekstual, serta memperluas media pembelajaran dengan memanfaatkan jejaring sosial, ketiga strategi tersebut diharapkan mampu mengurangi kejenuhan mahasiswa dan mampu menciptakan antusiasme mahasiswa dalam mengikuti perkuliahan daring.

\section{Daftar Pustaka}

Afriani, A. (2018). Pembelajaran Kontekstual (Cotextual Teaching and Learning) dan Pemahaman Konsep Siswa. Jurnal Al-Muta'aliyah, 1(3), 80-88.

Aji, R. H. S. (2020). Dampak Covid-19 pada Pendidikan di Indonesia: Sekolah, Keterampilan, dan Proses Pembelajaran. Salam: Jurnal Sosial Dan Budaya Syar i, 7(5), 395-402.

Creswell, J. W. (2007). Qualitative Inquiry and Research Design: Choosing Among Five Approaches. Thousand Oaks: Sage Publications.

Darmansyah. (2010). Strategi Pembelajaran Menyenangkan Dengan Humor. Jakarta: Bumi Aksara. 
Dewi, W. A. F. (2020). Dampak Covid-19 Terhadap Implementasi Pembelajaran Daring di Sekolah Dasar. Edukatif: Jurnal Ilmu Pendidikan, 2(1), 55-61.

Direktorat Tenaga Kependidikan. (2008). Strategi Pembelajaran dan Pemilihannya. Jakarta: Departemen Pendidikan Nasional RI.

Djamaroh, S. B. (2002). Strategi Belajar Mengajar. Jakarta: Rineka Cipta.

Fahlevi, F. (2020). Kemendikbud: Hanya 51 Persen Pembelajaran Jarak Jauh yang Efektif Menggunakan Internet. Retrieved October 21, 2020, from https://www.tribunnews.com/nasional/2020/05/28/kemendikbud-hanya-51persen-pembelajaran-jarak-jauh-yang-efektif-menggunakan-internet

Fandianta., Sanjaya, G. Y., \& Widyandana. (2013). Meningkatkan Pengetahuan Mahasiswa Dengan Memberikan Fleksibilitas Belajar Mengajar Melalui Metode Blended Learning. Jurnal Pendidikan Kedokteran Indonesia, 2(2), 1-8.

Fathurrohman, P., \& Sutikno, M. S. (2007). Strategi Belajar Mengajar Melalui Penanaman Konsep Umum \& Konsep Islami. Jakarta: Refika Aditama.

Freiberg, H. J., \& Driscoll, A. (1992). Universal Teaching Strategies. Boston: Allyn \& Bacon.

Hakim, T. (2004). Belajar Secara Efektif. Jakarta: Pusaka Pembangunan Swadaya Nusantara.

Jamaluddin, D., Ratnasih, T., Gunawan, H., \& Paujiah, E. (2020). Pembelajaran Daring Masa Pandemik Covid-19 Pada Calon Guru: Hambatan, Solusi Dan Proyeksi. Bandung. Retrieved from http://digilib.uinsgd.ac.id/30518/1/Pembelajaran Daring Masa Pandemik Covid-19 Pada Calon Guru Hambatan\%2C Solusi Dan Proyeksi.pdf

Kadir, A. (2013). Konsep Pembelajaran Kontekstual di Sekolah. Dinamika Ilmu, 13(3), 17-38.

Kementerian Riset Teknologi dan Pendidikan Tinggi. (2016). Kebijakan Pendidikan Jarak Jauh dan E-Learning di Indonesia. Jakarta.

Khairani, M. (2013). Psikologi Belajar. Yogyakarta: Aswaja Presindo.

Masriadi. (2020). Suka Duka Kuliah Online Saat Pandemi Corona: Dosen dan Mahasiswa "Gaptek" hingga Mengeluh Boros Paket Data. Retrieved July 2, 2020, from https://regional.kompas.com/read/2020/04/07/22044941/suka-duka-kuliahonline-saat-pandemi-corona-dosen-dan-mahasiswa-gaptek?page=all

Mubiar, A. (2011). Model Konseling Kognitif-Perilaku Untuk Menangani Kejenuhan Belajar Mahasiswa. Bandung. Retrieved from http://file.upi.edu/Direktori/FIP/JUR._PGTK/197708282003121MUBIAR_AGUSTIN/Laporan_Hibah_Doktor-Mubiar-/Artikel_Mubiar.pdf

Muna, N. R. (2013). Efektifitas Teknik Self Regulation Learning Dalam Mereduksi Tingkat 
Kejenuhan Belajar Siswa di SMA Insan Cendekia Sekarkemuning Cirebon. Jurnal Holistik, 14(2), 57-78.

Mustakim. (2020). Efektivitas Pembelajaran Daring Menggunakan Media Online Selama Pandemi Covid-19 Pada Mata Pelajaran Matematika. Al Asma: Journal of Islamic Education, 2(1), 1-12.

Putra, I. P. (2020). Enam Penyebab Kuliah Daring Tak Optimal di Indonesia. Retrieved August 17, 2020, from https://www.medcom.id/pendidikan/newspendidikan/1bVjAP7b-enam-penyebab-kuliah-daring-tak-optimal-di-indonesia

Sugiyono. (2010). Metode Penelitian Kuantitatif, Kualitatif $\mathcal{E}$ Reseach and Development. Bandung: Alfabeta.

Syah, M. (2011). Psikologi Belajar. Jakarta: Rajawali Press.

Usman. (2018). Komunikasi Pendidikan Berbasis Blended Learning dalam Membentuk Kemandirian Belajar. Jurnalisa, 4(1), 136-150. 